\title{
THE CANARY RECORD OF THE EVOLUTION OF THE NORTH ATLANTIC PLIOCENE: NEW 40AR/39AR AGES AND SOME NOTABLE PALAEONTOLOGICAL EVIDENCE
}

\author{
Meco, J. ${ }^{\text {a }}$ Koppers, Anthony A. Pb; Miggins, Daniel P. ${ }^{\text {b; Lomoschitz, Alejandro }}$; Betancort- \\ Lozano, Juan Francisco ${ }^{a}$
}

\begin{abstract}
a Departamento de Biología, Universidad de Las Palmas de Gran Canaria (ULPGC), Canary Islands, Las Palmas de Gran Canaria, Spain

b College of Earth, Ocean and Atmospheric Sciences, Oregon State University, Corvallis, OR, United States

c Instituto de Oceanografía y Cambio Global (IOCAG), Universidad de Las Palmas de Gran Canaria (ULPGC), Canary Islands, Las

Palmas de Gran Canaria, Spain
\end{abstract}

\section{Abstract}

Two new 40Ar/39Ar ages $(*)$ and previously published K/Ar ages of basaltic pillow lava flows are coeval with closely-related fossiliferous marine layers, allowing us to establish the beginning (5.8; 5.0; 4.8Ma at Ajuí, Fuerteventura Island and 4.8 $\pm 0.03 \mathrm{Ma}(2 \sigma)^{*}$ at Tamaraceite) and a middle stage (4.20 $\pm 0.18 \mathrm{Ma}(2 \sigma)^{*}$ at La Esfinge in Gran Canaria Island) of Early Pliocene marine deposits in the Canary Islands. Here the presence of tropicopolitan fossils (Megaselachus megalodon, Janthina typica) suggests the influence of a possible Central American Circumtropical Current during the Pliocene and in the North Atlantic basin. The presence of both Janthina typica and the Argonauta argo also indicate the occurrence of tropical storms in the area of the Canary Islands around that time. In addition, the pillow lava flow at La Esfinge overlies a submarine pyroclastic layer containing Ostrea offreti that was preserved in its life position, a fossil from the terminal Miocene and commonly found on the south eastern Iberian Peninsula. At La Cruz on Fuerteventura Island, a dune formed above marine deposits lies beneath a palaeosol and a basaltic lava flow that was K/Ar dated at 2.9Ma. Near El Mármol in Gran Canaria the corresponding palaeosol lies between lava flows $\mathrm{K} / \mathrm{Ar}$ dated at $3 \mathrm{Ma}$. Based on these observations, we argue in this paper that the first appearance of the Canary Current, the eastern boundary current of the North Atlantic sub-tropical gyre, occurred between 4.2Ma and 2.9Ma ago. This was followed by a major sea level drop (of about $40 \mathrm{~m}$ ) and the formation of a first fossil-bearing palaeosol which indicate that major climate change that took place around 2.952.82Ma. 